\title{
Mineralogy of Iza Cave (Rodnei Mountains, N. Romania)
}

\author{
Tudor Tămaşs, ${ }^{1,2}$ Ferenc Kristály ${ }^{3}$ and Lucian Barbu-Tudoran ${ }^{4}$
}

\begin{abstract}
:
Tămaş T., Kristály F. and Barbu-Tudoran L. 2011. Mineralogy of Iza Cave (Rodnei Mountains, N. Romania) International Journal of Speleology, 40 (2), 171-179 Tampa, FL (USA). ISSN 0392-6672. DOI 10.5038/1827-806X.40.2.9

The secondary minerals from Iza Cave result from the interactions of karst water and/or cave atmosphere with a variety of sedimentary and metamorphic rocks. The cave passages expose at various extents Eocene limestones and conglomerates, Oligocene black shales, Upper Precambrian micaschists, marble and dolomitic marble and associated ore deposits. Twelve secondary minerals identified in the cave (carbonates, sulfates, phosphates, oxides and hydroxides, and silicates) are presented in this study. Calcite, aragonite, gypsum, brushite and hydroxylapatite are the components of common speleothems in the limestone, dolomite and conglomerate areas of the cave. Ankerite crusts are related to areas with pyrite mineralization within the metamorphic carbonate rocks. Goethite, jarosite, hematite and gypsum form various speleothems in the sectors within micaschists and conglomerates. Large weathering deposits occurring in passage areas developed within micaschists consist of illite, kaolinite, jarosite, goethite, gypsum and alunite. The extent of the weathering deposits occurring on non-karst rocks in the underground environment makes this cave a particularly interesting site for studies of water-rock interactions.
\end{abstract}

Keywords: cave minerals, contact cave, lithology, weathering deposits, Rodnei Mountains, Romania

Received 21 January 2011; Revised 14 March 2011; Accepted 27 April 2011

\section{INTRODUCTION}

Minerals forming speleothems are the results of complex interactions between bedrock, circulating water, and sediments of various sources (e.g. Hill \& Forti, 1997; Onac, 2000; Forti et al., 2006; Ford \& Williams, 2007; Palmer, 2007). In most caves formed in limestones, the minerals resulted from bedrock water interaction are calcite, less often aragonite, and gypsum (Hill \& Forti, 1997). Peştera Iza (Iza Cave) from the Rodnei Mountains (Maramureş county, East Carpathians, N Romania) crosses Eocene - Oligocene sedimentary and Precambrian metamorphic rocks: limestones, conglomerates, black shales, micaschists, marble, dolomitic marble and associated ore deposits (Fig. 1), and is so far the only cave known in Romania to develop in such a complex lithological setting (Tămaş, 2009a; Tămaş et al., 2009). Micaschists, conglomerates and the ore deposits exposed by the cave streams are subject to weathering due to the high humidity of the subterranean environment, thus

\footnotetext{
${ }^{1}$ Department of Geology, "Babeş-Bolyai" University, Kogălniceanu 1, 400084 Cluj-Napoca, Romania.

${ }^{2}$ Romanian Academy, "Emil Racoviță” Institute of Speleology, Clinicilor 5, 400006 Cluj-Napoca, Romania (tudor.tamas@ubbcluj.ro).
}

${ }^{3}$ Department of Mineralogy and Petrology, Institute of Mineralogy and Geology, University of Miskolc, Miskolc Egyetemváros, 3515, Hungary (askkf@uni-miskolc.hu).

${ }^{4}$ Electron Microscopy Center, Department of Experimental Biology, "Babeş-Bolyai" University, Clinicilor 5, 400006 ClujNapoca, Romania (1barbu@biolog.ubbcluj.ro). creating large weathering deposits in places above the present level of the cave stream. Samples from one such weathering deposit in the cave had been previously analyzed by means of X-ray diffraction (XRD) and transmission electron microscopy (TEM) (Viehmann et al., 1979, 1981).

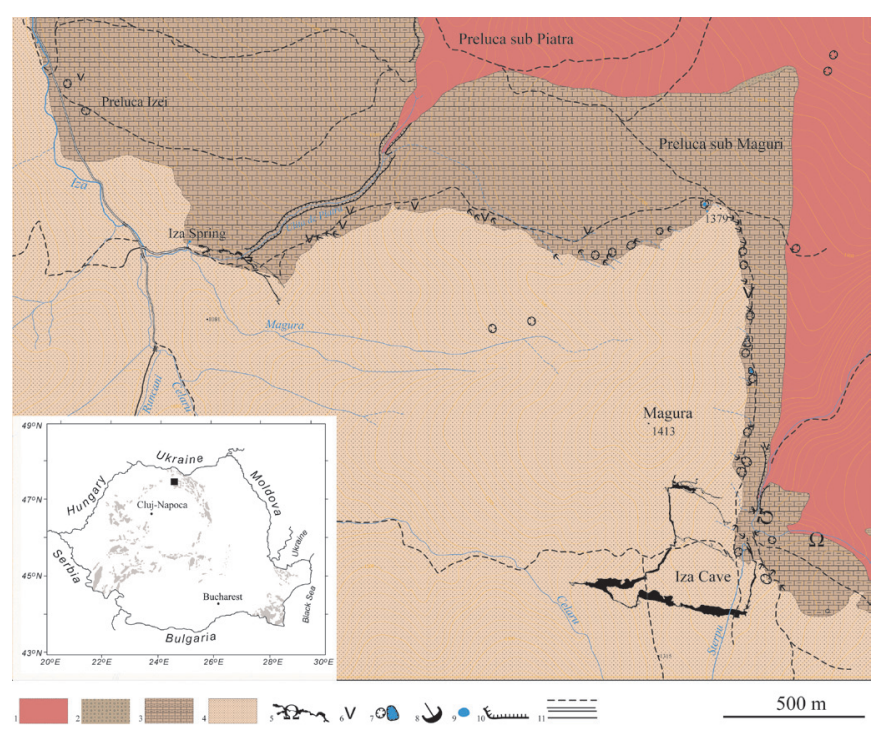

Fig. 1. Map of the Izvorul Izei karst area (modified from Mureşan, 2010); 1. Upper Precambrian crystalline rocks (undifferentiated): micaschist, quartzite, marble, dolomitic marble; 2. Lutetian conglomerate; 3. Priabonian limestone; 4 . Oligocene shales and sandstones; 5 caves; 6 . potholes; 7 . dolines 8 ; ponors; 9 . karst springs; 10 cliffs and gorges; 11. roads. Inset: Location of Izvorul Izei karst area (black square) on the map of Romanian karst. 
1. Goethite crusts on micaschist

2. Weathering deposit on micaschist, goethite stalactites, hematite spots on conglomerate

3. Kaolinite, jarosite, residual pyrite, quartz and mica in partly weathered micaschist

4. Aragonite crusts and crystals, calcite speleothems on conglomerate ceiling

5. Goethite and jarosite crusts on micaschist

6. Goethite gours on micaschist

7. Jarosite-goethite wall crusts on micaschist

8. Large weathering deposit:

jarosite, gypsum, kaolinite, illite

9. Aragonite and calcite on conglomerate

10. Jarosite, hematite, ankerite wall crusts

11. Main fault, micaschist/limestone contact: jarosite, kaolinite, goethite

12. Weathering deposit: kaolinite, illite, jarosite, goethite

13. Altered mineralization on fissures in marble

14. Altered mineralization (mainly pyrite): goethite, jarosite, gypsum, aragonite, ankerite

15. Paleokarst in marble, hematite

16. Altered conglomerate

17. Altered cobbles in limestone

18, 19. Rusty chains: goethite, jarosite; gypsum crusts and crystals, calcite helictites on limestone

$20,22,25,28,29$. Calcite speleothems (28 hydroxylapatite)

21,24 . Gypsum crusts

23,27 . Brushite, hydroxylapatite, gypsum

26. Jarosite, goethite in altered ore fragments from limestone
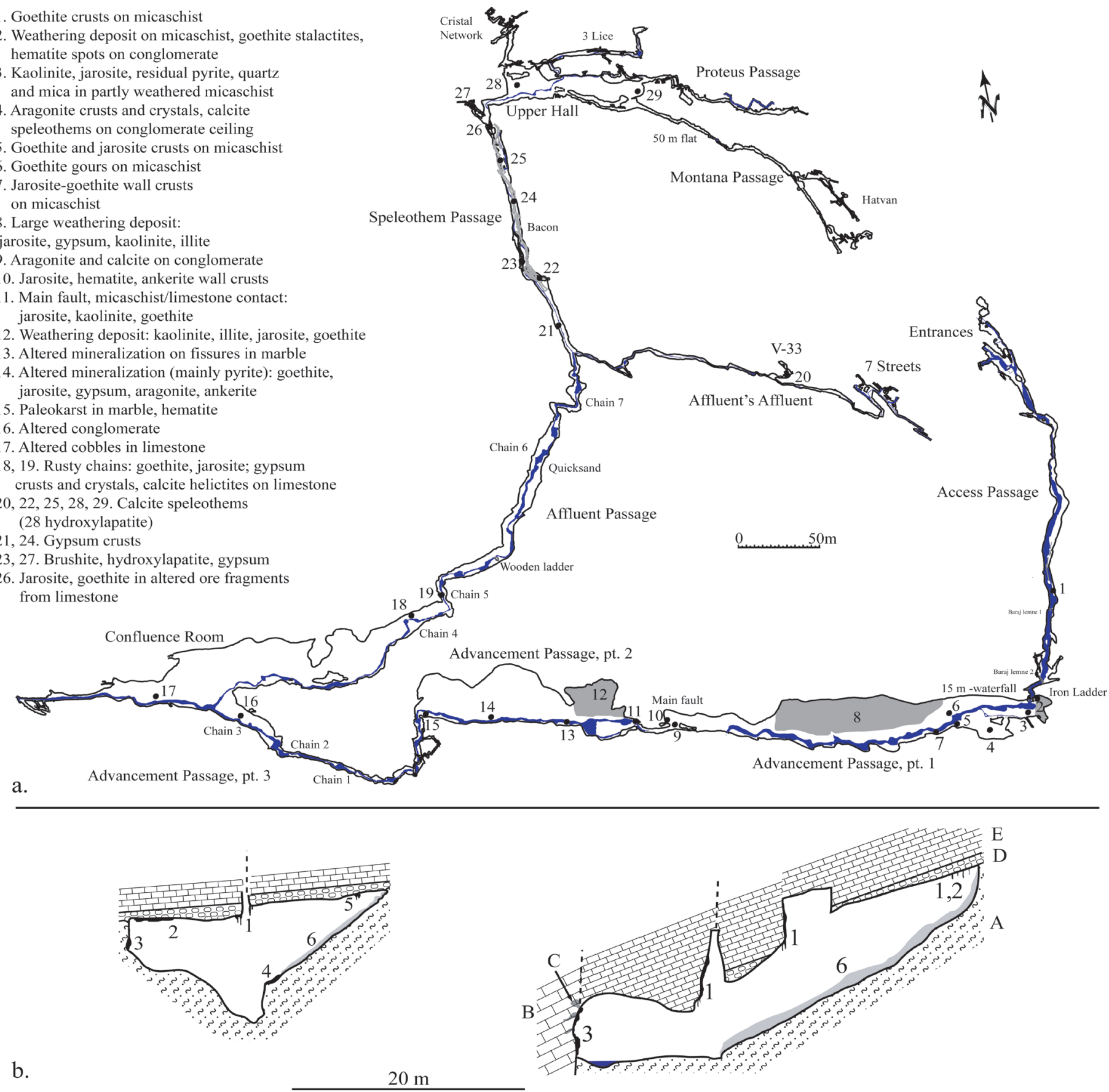

b.

$20 \mathrm{~m}$

Fig. 2. a) Plan of Iza Cave showing the location of secondary deposits and various mineral occurrences (numbered); b) Typical cross - sections of the Advancement Passage showing the location of various speleothems in relation to the lithology of the host rocks (A micaschist, B - marble, C - pyrite mineralization, D - conglomerate, E - limestone; 1, - calcite speleothems; 2 - aragonite speleothems; 3 - goethite and jarosite speleothems; 4 . goethite speleothems; 5 . goethite, calcite, hematite speleothems; 6 . weathering deposit).

In 1979, the explored length of the Iza Cave was 2.5 $\mathrm{km}$. In the ' 80 's the entrance passage was blocked by tree trunks and visitors no further reached its deeper parts until 2000, when the cave got reopened. Since then, the members of the Iza Cave Project have mapped $4.4 \mathrm{~km}$ of passages, providing a detailed picture of the lithologic contacts between the formations that make up the geologic setting (Sahy et al., 2008; Tămaş et al., 2009; Mureşan, 2010). The purpose of this paper is to describe the secondary minerals from the Iza Cave and their relation with the lithology of the host rocks. In this respect, over a hundred samples have been collected from various secondary deposits within the cave, especially from the Advancement Passage, although cave deposits similar to the ones sampled were identified along the whole cave (Fig. 2a).

\section{SITE LOCATION AND GEOLOGIC SETTING}

The Iza River is an important left-side tributary to the Tisa, which forms a part of the northern border of Romania. Its origins are in the NW part of the Rodnei Mountains, in the territory of the villages of Moisei and Săcel (East Carpathians, Maramureş County). Izvorul Albastru al Izei (The Blue spring of Iza, 1025 $\mathrm{m}$ a.s.1.), or shortly Izvorul Izei (Iza spring) is the well- 
known karst source of the river and drains the SE half of an Upper Eocene (Priabonian) limestone band. The main entry point for the surface waters in the system is the Iza Cave (1250 $\mathrm{m}$ a.s.1.) (Fig.1).

The crystalline basement of the area belongs to the Rebra Series, Upper Precambrian (Bercia et al., 1976; Kräutner et al., 1982) and consists of quartz micaschists with garnet, which underwent a Variscan retromorphism to the greenschist facies (Balintoni, 1997; Strutinski et al., 2006). The micaschists are associated with crystalline limestones and dolomites containing in places stratiform lead-zinc pyrite mineralization (Kräutner et al., 1978, 1982; Udubaşa et al., 1983). Although in the northern part of Rodnei Mountains they don't form economically important accumulations, on the southern side of the mountains the ore-containing carbonates were mined at Valea Blaznei and Gusset (Socolescu et al., 1961; Udubaşa et al., 1983). The components of the mineralizations are pyrite, sphalerite and galena, with subordinate chalcopyrite, pyrrhotite, magnetite, rutile, ilmenite, arsenopyrite, tetrahedrite, barite and cymrite (Udubaşa, 1981).

The Priabonian limestone band is approximately $10 \mathrm{~km}$ long, $3 \mathrm{~km}$ large and 40-50 $\mathrm{m}$ thick and overlies a thin discontinuous bed of Lower Eocene (Lutetian) conglomerates disposed transgressively over the crystalline rocks (Fig. 1). The limestones are covered by Oligocene black shales and sandstones (Kräutner et al., 1982; Mureşan, 2010). Most of the carbonate succession has a high siliciclastic input (Sahy et al., 2008). The sedimentary rocks are disposed in a monocline dipping westward at $10-20^{\circ}$ and discordantly overlie the crystalline basement (Kräutner et al., 1982).

\section{CAVE DESCRIPTION AND LITHOLOGY}

Iza Cave (Figs. 1, 2a) is an active ponor cave consisting of several cave streams which create a dendritic network. The two main cave streams, each collecting several tributaries, join near a sump situated $181 \mathrm{~m}$ below Entrance 3. The three entrances are opened within the Priabonian limestones. Detailed descriptions of the Iza Cave were published first by Viehmann et al. (1979) and more recently by Tămaş (2009a, b) and Tămass et al. (2009). The contact between the sedimentary and the metamorphic rocks is reached at $50 \mathrm{~m}$ from the entrance and can be followed at various levels in the walls along most of the cave, up to the Upper Room, developed only in limestones. The largest cross-sections occur in passages developed in the metamorphic rocks $(15 \mathrm{~m}$ high, $40 \mathrm{~m}$ large).

The Advancement Passage of the cave (Fig. 2a, b) consists of 3 very large sectors, developed E-W along faults and connected by narrow canyons. The cave passages expose micaschists and metamorphic carbonate rocks, as well as conglomerates and limestones (Figs. 2b, 3). Pyrite mineralization occurs at various sites within the cave, as lenses in the metamorphic carbonates and micaschists, and blocks or cement in brecciated areas of the walls (Fig. 4 a). Pebbles, large cobbles and even boulders of the metamorphic rocks and associated ore deposits can be

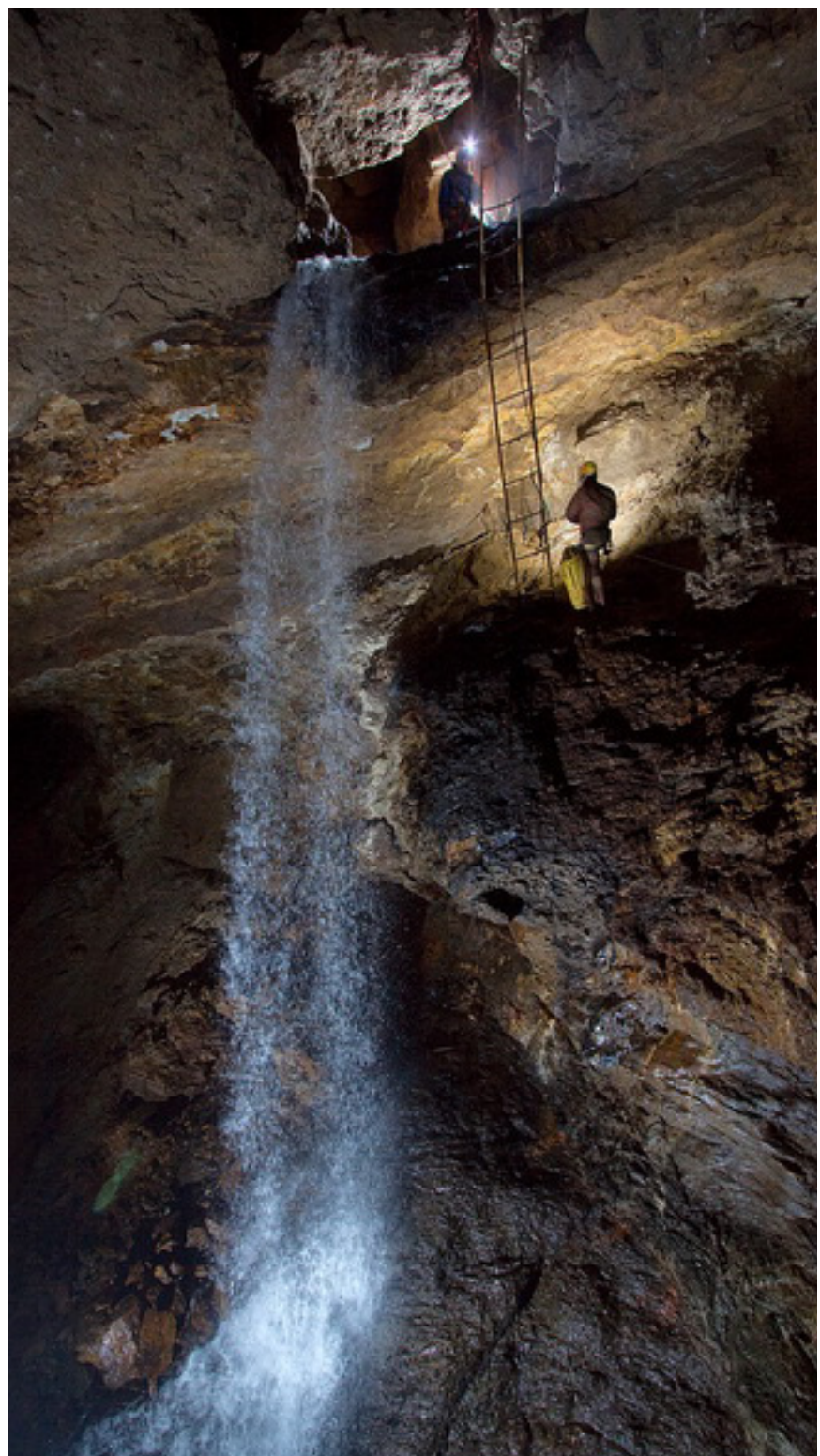

Fig. 3. Geological setting at the junction of the Access Passage with the Advancement Passage in Iza Cave (The $15 \mathrm{~m}$ waterfall - sampling points 2 and 3 in Fig. 2a): the waterfall starts from a 1 $\mathrm{m}$ ledge of conglomerates separating the Priabonian limestones above and the crystalline rocks below (photo by A. Posmoşanu).

observed all along the cave walls in the conglomerates and to a lesser extent in the limestones (Fig. 4b). The floor of the Advancement Passage dips at 30$40^{\circ} \mathrm{SW}$ generally following the micaschist dipping. In the large sectors situated in the upstream part of the passage, the weathering deposits have formed on the exposed bedrock, along the areas not affected by flooding and where the micaschists or conglomerates are not covered by detrital sediments. In a rough estimate of its extent, the largest weathering deposit covers a surface of more than $5000 \mathrm{~m}^{2}$ and is in places more than $30 \mathrm{~cm}$ thick. The degree of weathering is variable: in parts large blocks still keep the older internal structure of the host rock. On longer, less steep slopes, where trickles of water cross the conglomerate ceiling, mass flows can form (Fig. 5a). The color of the weathering deposit varies from white to yellow, grey to reddish brown, depending on the dominance of a certain secondary iron mineral. 


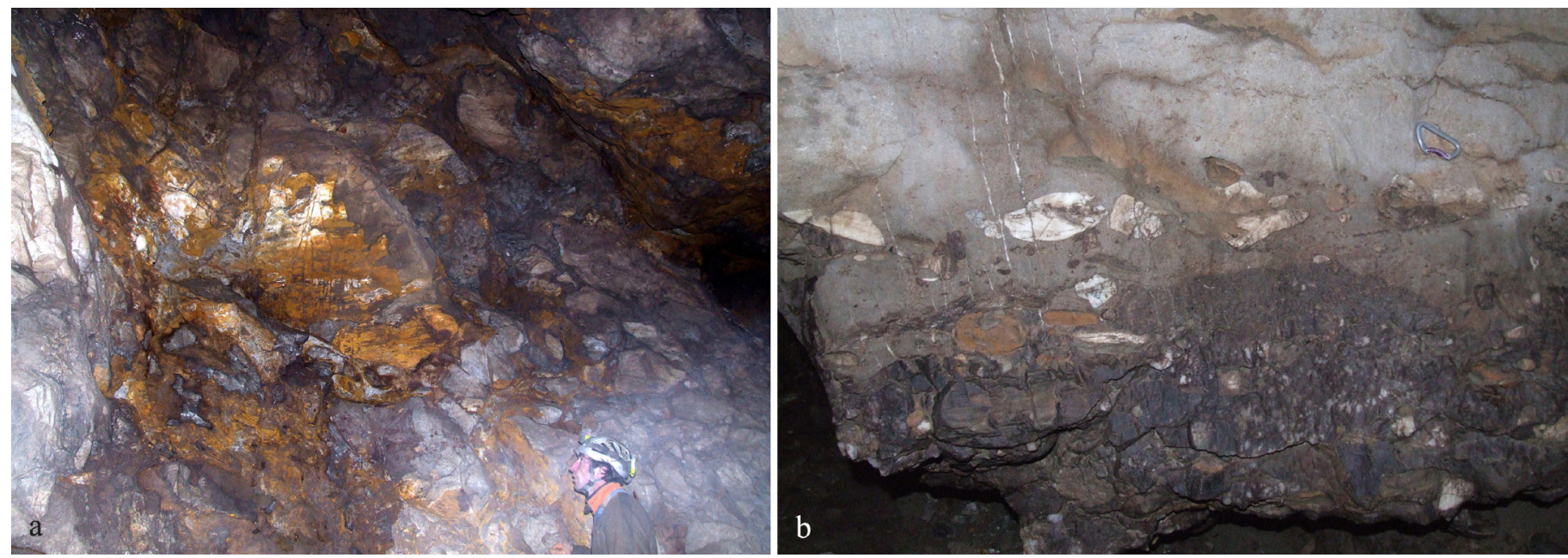

Fig. 4. a) Mineralized marble breccia with extensive goethite deposits on the left wall of the Advancement Passage; b) Lutetian conglomerates and transition to Priabonian limestones in the left wall of the Confluence Room: the "rusty" cobbles near the top of the conglomerates consist of oxidized mineralization (karabiner on top right for scale).

On the steep, almost vertical southern walls of the Advancement Passage, water seeping along schistosity or at the limestone-conglomeratemicaschist contacts has deposited brown-black stalactites, reddish powdery crusts and layered crusts of yellow-brownish crumbly material with either orange or blood-red earthy spots or stains composed of iron oxides and sulfates (Fig. 5a).

Along the Affluent series, until the Upper Hall, all passages follow the contact between micaschists and limestones, the conglomerates being replaced by scarce micaschist and/or marble blocks in a carbonate cement. The Fossil Level - Speleothem Passage complex crosses the whole limestone sequence, exposing also the Oligocene black shales in the passage ceilings. Weathering deposits are less extensive here due to the smaller size of the passages, which also are developed less and less in metamorphic rocks as one climbs upstream and calcite and gypsum speleothems predominate.

\section{ANALYTICAL METHODS}

Sample separations were made with a Nikon SMZ1500 stereo zoom microscope, equipped with a fiber-optic ring illuminator and a DS-5M standard CCD camera. The samples were analyzed by means of X-ray powder diffraction (XRD), using a Philips PW 1710 diffractometer and a Bruker D8 Advance diffractometer (both with $\mathrm{CuK}_{\mathrm{a}}, \lambda \mathrm{a}^{1}=1.54060 \AA$ ) ), with a step of $0.02^{\circ} 2 \theta$ for particle-oriented clay fraction, and $0.04^{\circ} 2 \theta$ for bulk samples. Mineral species were identified based on the PDF2 (2005) database. The samples were examined by transmission and scanning electron microscopy at the Electron Microscopy Center, University of Cluj on a JEOL - JEM 1010 (TEM) operated at $80 \mathrm{kV}$, with samples sonicated in distilled water and deposited onto carbon coated $\mathrm{Cu} 400$ mesh grids, and a JEOL JSM5510LV (SEM) operated at $15 \mathrm{kV}$, with samples deposited onto carbon sticky tabs and $5 \mathrm{~nm}$ gold sputter-coated (Agar Automatic SputterCoater, Agar Scientific, UK).

\section{RESULTS AND DISCUSSION}

The secondary mineral associations found in the Iza Cave comprise so far carbonates (calcite, aragonite, ankerite,), phosphates (brushite, hydroxylapatite), oxides and hydroxides (goethite, hematite), sulfates (gypsum, jarosite, alunite) and silicates (illite and kaolinite). The identification of these minerals was based mainly on their diffraction patterns. Electron microscopy was used in some cases to determine crystal shapes and morphologies.

In addition to the minerals above, dolomite, pyrite, muscovite and quartz have also been found in some samples, but they are not of secondary origin. Dolomite together with pyrite occurs in the areas of the cave walls where breakdown has exposed unaltered mineral deposits included in crystalline carbonate rocks. Quartz and partly muscovite and pyrite are the main residual minerals in the weathering deposits formed on the micaschists and conglomerates in the areas where these rocks were exposed through erosion by the cave streams.

\section{Carbonates}

Calcite $\left(\mathrm{CaCO}_{3}\right)$ occurs in common speleothems such as stalactites, stalagmites, flowstones and also as pool crystals and crusts. Stalactites are more common along the faults from the ceiling of the Advancement Passage (where they have no corresponding stalagmites, which have been probably periodically washed away by the cave stream) and in the upper part of the Affluent section, especially along the Speleothem Passage and in the Upper Hall, the best decorated parts of the cave (Fig. 2a).

Aragonite $\left(\mathrm{CaCO}_{3}\right)$ speleothems were found in several places along the Advancement Passage, on conglomerate ceilings and walls, where it occurs as needle-like crystals, crusts and globular formations (Fig. 2a). In secondary crusts associated with pyrite mineralization, aragonite forms levels along with gypsum, calcite and ankerite. In all occurrences aragonite formed from $\mathrm{Mg}$-rich solutions resulted from the dissolution of metamorphic dolomite occurring either as levels in the crystalline rocks or as pebbles in the conglomerates. 

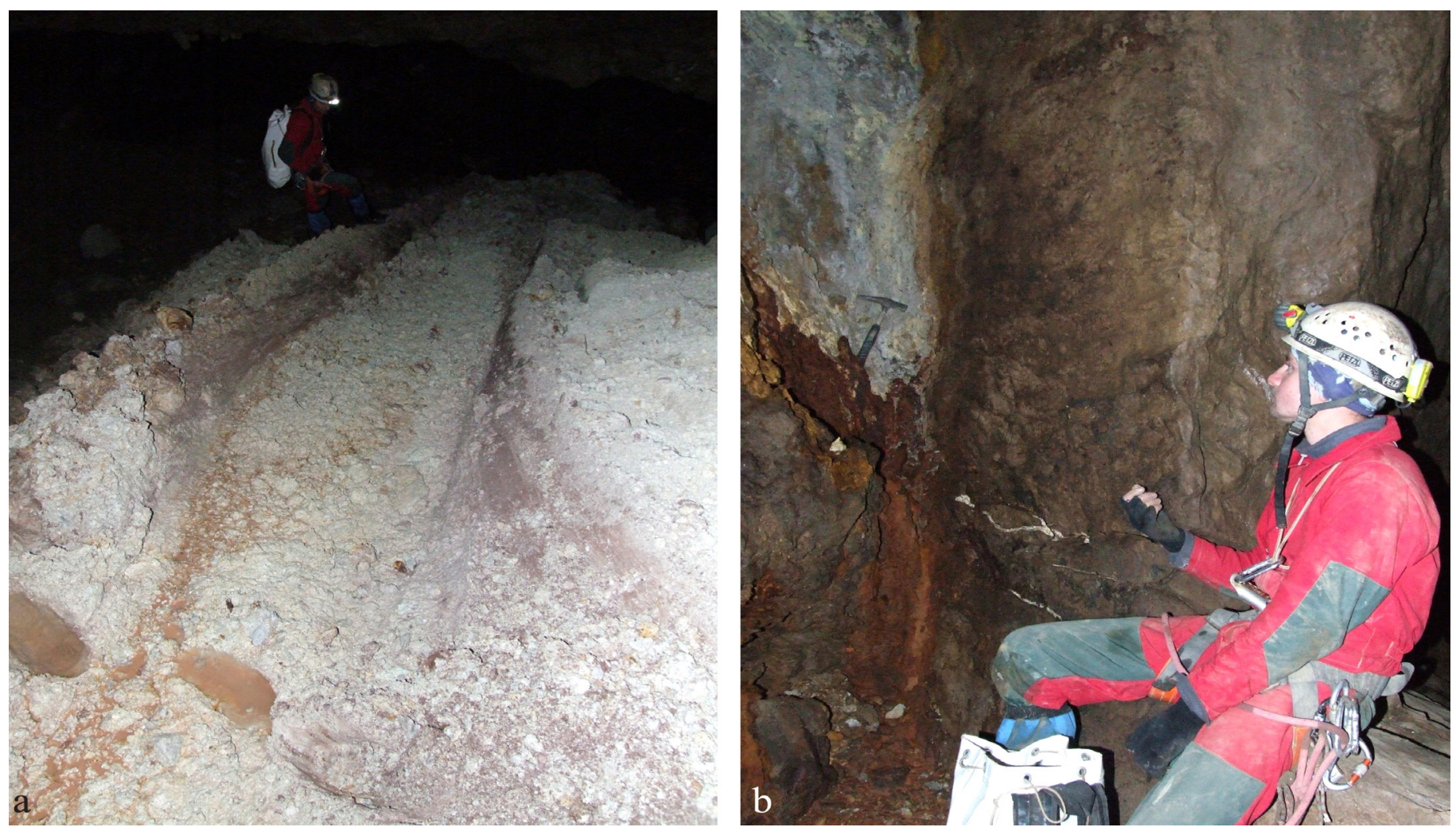

Fig. 5. a) "Mass flow" in a weathering deposit (sampling point 8 in Fig. 2a); b) Weathered micaschists and Upper Eocene limestones at the Main Fault point (sampling point 10 in Fig. 2a);

Ankerite $\left[\mathrm{Ca}(\mathrm{Fe}, \mathrm{Mg}, \mathrm{Mn})\left(\mathrm{CO}_{3}\right)_{2}\right]$ uncommon in caves, was identified in Iza Cave in two occurrences: a) grey carbonate and sulphate crusts associated with the ore deposits, and b) reddish white crusts formed on conglomerate walls (Fig. 2a). It was identified by its XRD pattern (Fig. 6a). In the former occurrence, where it is associated with gypsum, quartz and aragonite its origin is not clear, in the second it is most probably a supergene mineral, occurring in the vicinity of goethite and hematite spots. The source of cations is the Lutetian conglomerates, which include pebbles of both pyrite mineralization and metamorphic carbonate rocks. This is the third occurrence of ankerite in Romanian caves, after the ones in Peştera Mare din Cheile Runcului (Onac, 1992) and Movile Cave (Diaconu \& Morar, 1993). Other world occurrences include caves in Ukraine, South Korea and Turkmenistan (Hill \& Forti, 2007).

\section{Phosphates}

Brushite $\left(\mathrm{CaHPO}_{4} \cdot 2 \mathrm{H}_{2} \mathrm{O}\right)$ occurs either as small nodules in fine sands, associated with gypsum crusts and crystals, or as powdery deposits on the walls of the Speleothem Passage (Fig. 2a), whereas hydroxylapatite $\left[\mathrm{Ca}_{5}\left(\mathrm{PO}_{4}\right)_{3}(\mathrm{OH})\right]$ forms black crusts covering pebbles or calcite speleothems in the Speleothem Passage and in the Upper Hall (Fig. 2a). Both these phosphates are common cave minerals and resulted from the interaction of limestones and/or calcite speleothems with small bat guano deposits in slightly different $\mathrm{pH}$ conditions - below 6 for brushite and above 6 for hydroxylapatite (Hill \& Forti, 1997).

\section{Iron oxides and hydroxides}

Goethite $[\mathrm{FeO}(\mathrm{OH})]$ is widely spread in the Iza Cave on a great variety of substrates (Figs. 2a, 7): micaschists, marble, conglomerates, limestones and various consolidated cave sediments, even on the iron chains used for rigging during the first exploration of the cave in the '70's. Cryptocrystalline goethite is the main component of stalactites, gours and microgours and may also form yellow, brown or black layered crusts in the weathering deposits (Figs. $6 b, 7)$.

Hematite $\left(\mathrm{Fe}_{2} \mathrm{O}_{3}\right)$ occurs at the Iron Ladder and in several other places along the Advancement Passage as dark-red powdery spots or crusts covering the weathered micaschist or conglomerate walls (Figs. 2a, 6c, 7a). Although it may sometimes indicate hydrothermal conditions (Hill \& Forti, 1997; Hill, 1999), in the Iza Cave hematite is most likely a lowtemperature mineral, formed through the dehydration of iron hydroxides in strongly ventilated areas of the passages. Most hematite samples analyzed by XRD show a low degree of crystallinity.

\section{Sulfates}

Gypsum $\left(\mathrm{CaSO}_{4} \cdot 2 \mathrm{H}_{2} \mathrm{O}\right)$ is the most widespread mineral throughout the cave, occurring on all types of substrates as tiny acicular crystals, always under $1 \mathrm{~cm}$ long, associated with iron hydroxides in areas within the WD and in weathered cobbles inside the conglomerate; crusts and acicular crystals in micaschists; crusts on limestones and sediments in the Affluent section. In the Fossil Level, millimeter-size transparent gypsum crusts cover completely the 

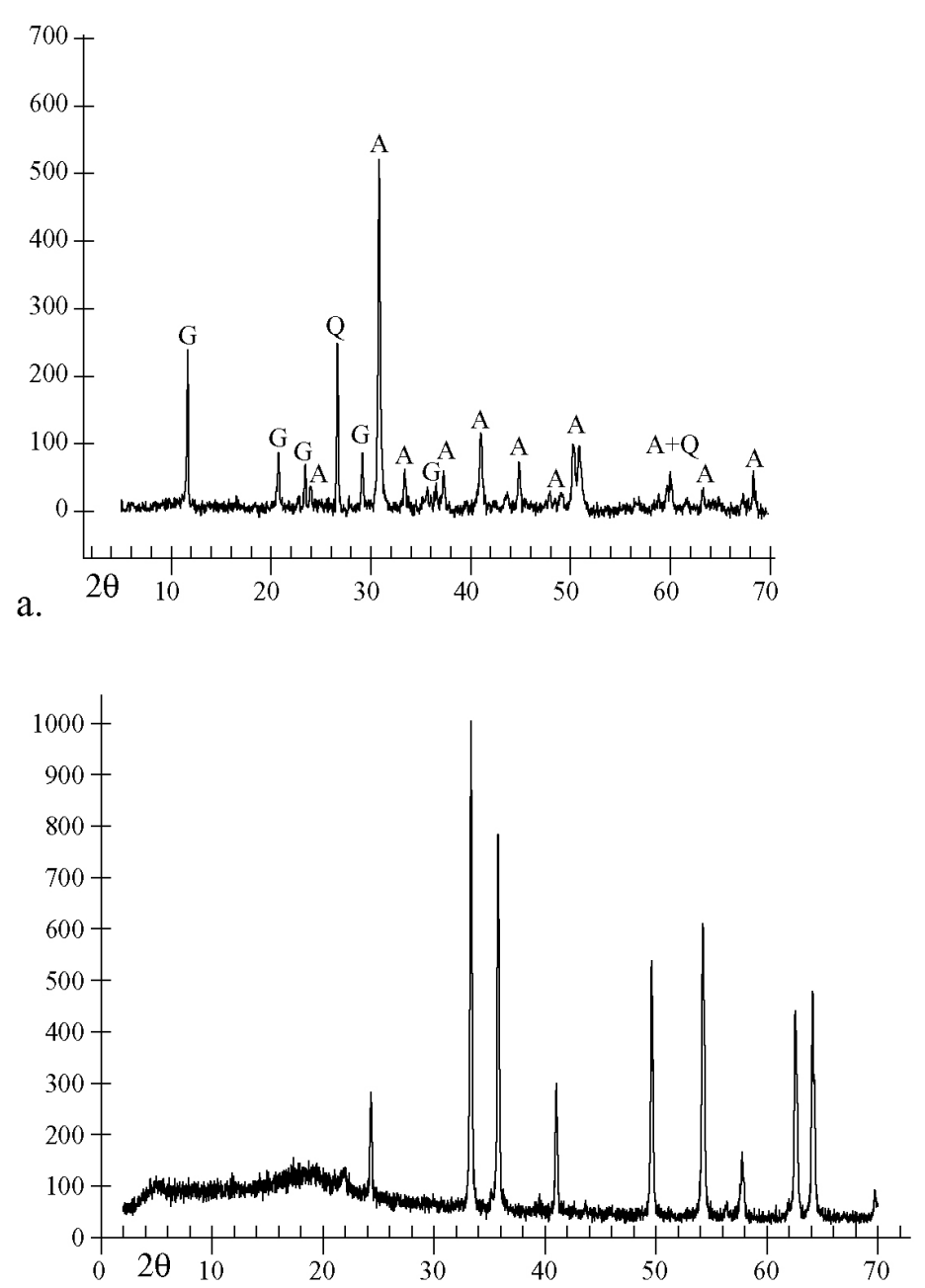

c.

Fig. 6. XRD patterns of: a) ankerite (A); b) goethite; c) hematite; d) jarosite (Q quartz, G - gypsum, K - kaolinite).

limestone walls of a canyon sector. Gypsum resulted from the oxidation of pyrite, present in the metamorphic rocks and associated ore, as well as in the limestones and in the Oligocene black shales covering the limestone all over the cave area.

Alunite $\left[\left(\mathrm{K}, \mathrm{Na}, \mathrm{H}_{3} \mathrm{O}\right) \mathrm{Al}_{3}\left(\mathrm{SO}_{4}\right)_{2}(\mathrm{OH})_{6}\right]$ is a minor constituent in the weathering deposits and it was determined only by its most intense XRD lines in two samples (Tămaș \& Ghergari, 2003) and its presence is therefore somewhat ambiguous. It probably resulted from the transformation of muscovite in the presence of sulfuric acid resulted from pyrite oxidation.

Jarosite $\left[\left(\mathrm{K}, \mathrm{Na}, \mathrm{H}_{3} \mathrm{O}\right) \mathrm{Fe}_{3}\left(\mathrm{SO}_{4}\right)_{2}(\mathrm{OH})_{6}\right]$ forms milimeter to centimeter-sized yellow-orange dusty nodules and crusts in various areas of the altered nonlimestone cave walls (Fig. 7$)$. Small $(1-3 \mu \mathrm{m})$, almost isometric rhombohedral crystals occur in the weathering deposits and in distinct levels in well-rounded pebbles inside the conglomerate (Fig. 8). Jarosite as a cave mineral has been reported from few caves in the United States, South Africa, Italy and Nepal, originating from sulfur bearing solutions, with the iron provided either by pyrite mineralization, basalts or schists (Hill \& Forti, 1997). The only other cave occurrences of jarosite in Romania are Fântâna lui Pavel (Tămaş \& Ungureanu, 2010) and Turia Cave (Onac $\&$ Forti, 2011). In the Iza Cave, jarosite formed in a
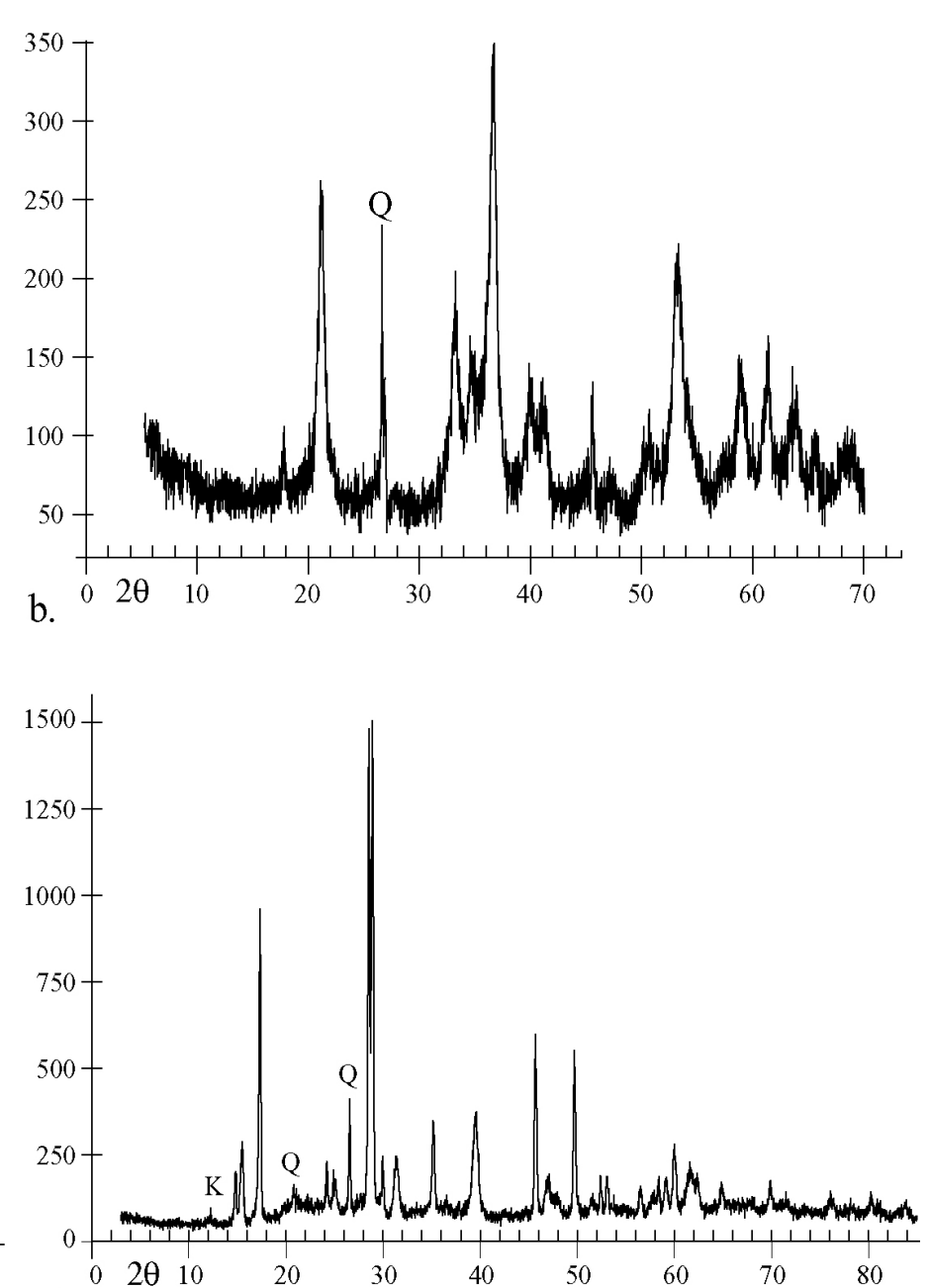

d. strongly acidic environment from the oxidation of pyrite, provided by the mineralization associated with the crystalline carbonate rocks, or disseminated in micaschists and conglomerates.

\section{Silicates}

The silicates identified so far by us in the Iza Cave are illite $\left[\mathrm{K}(\mathrm{Al}, \mathrm{Mg}, \mathrm{Fe})_{2}(\mathrm{Si}, \mathrm{Al})_{4} \mathrm{O}_{10}(\mathrm{OH})_{2},\left(\mathrm{H}_{2} \mathrm{O}\right)\right]$ and kaolinite $\left[\mathrm{Al}_{2} \mathrm{Si}_{2} \mathrm{O}_{5}(\mathrm{OH})_{4}\right]$, occurring in the large weathering deposits formed on micaschists along the Advancement Passage (Figs. 5a, 8b). They are definitely authigenic and have formed through weathering on the expense of muscovite and feldspars present in the micaschists. Illite and kaolinite have also been reported by Viehmann et al. $(1979,1981)$, in the socalled "Iza silicate complex", where they are associated with muscovite and quartz, residual minerals from the original host rocks.

\section{CONCLUSIONS}

Twelve secondary minerals belonging to five classes have been so far described from the Iza cave. Calcite, aragonite, and gypsum, common in normal limestone caves, occur in the passage sectors developed in limestones and conglomerates. Calcium phosphates occur in sections of the cave where bat 

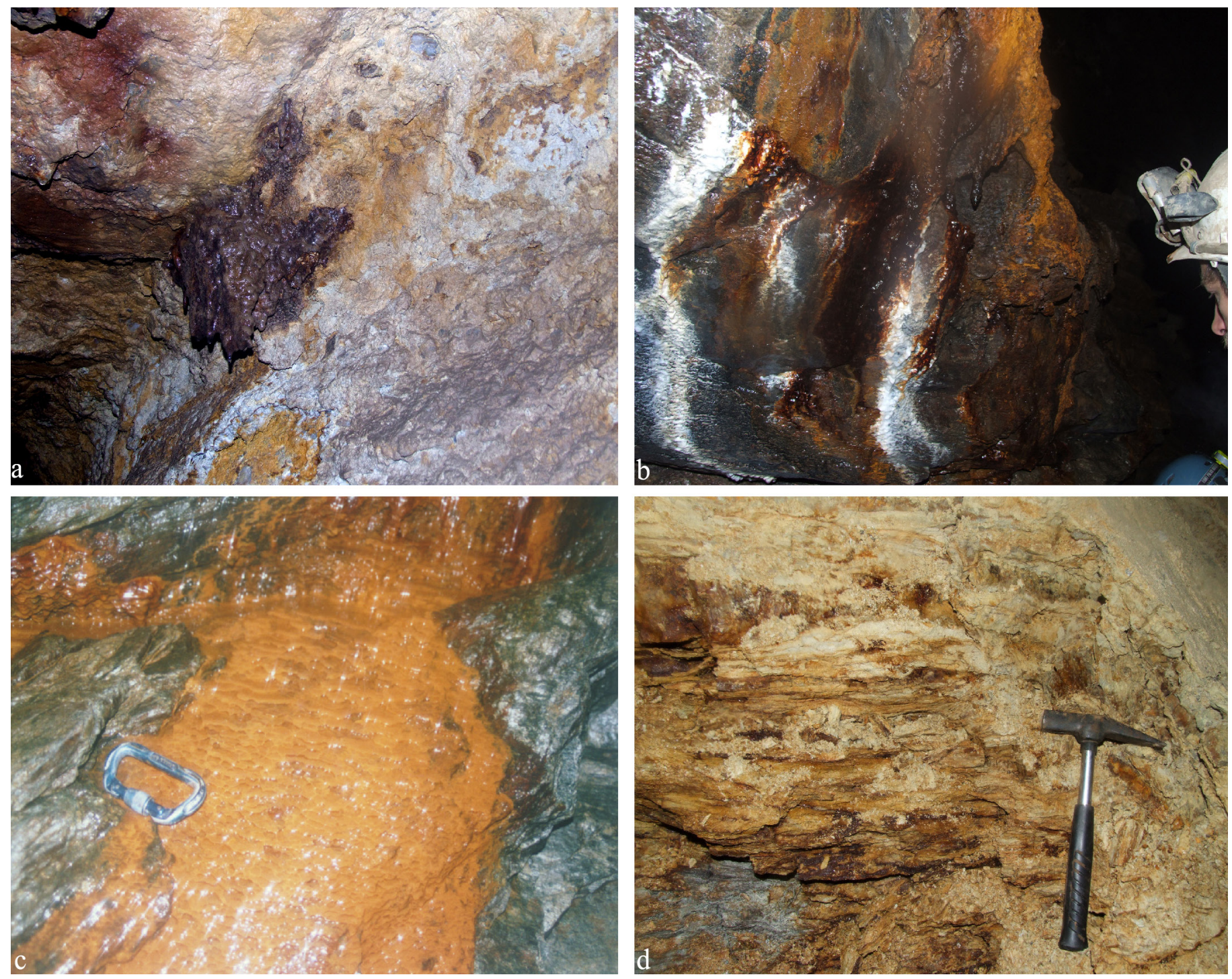

Fig. 7. Speleothems in the Advancement Passage of Iza Cave: a) Goethite stalactites (about $20 \mathrm{~cm}$ long); note the different coloured zones on the wall: reddish (predominantly hematitic), yellow (jarosite and goethite) and white (clay minerals and muscovite); b) Wall crusts and microgours; the upper yellowish crust is made up mainly by jarosite, while goethite and an amorphous mineral (probably allophane) are deposited below, indicating $\mathrm{pH}$ increase along the flow path; c) Goethite flowstone on retromorphosed micaschist; d) "Banded" weathering deposit; part of the original rock may be noticed in the bottom left corner.
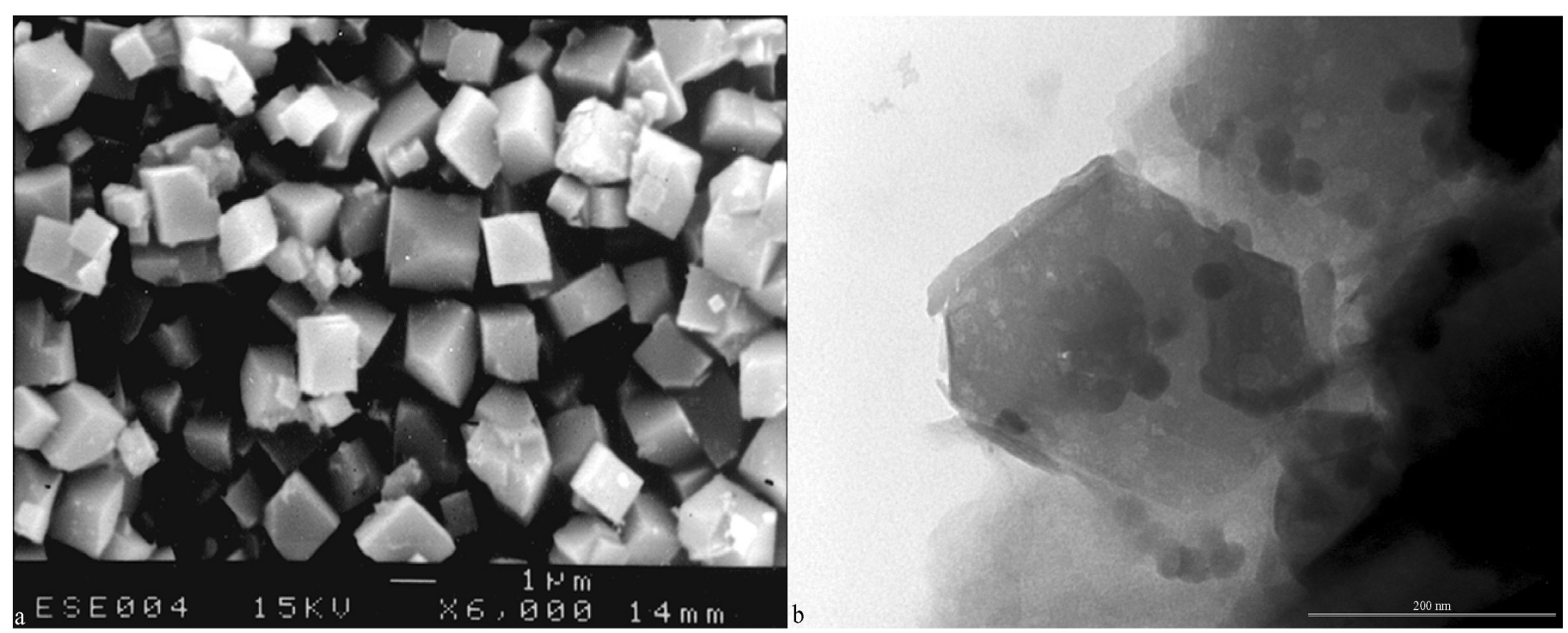

Fig. 8. a) SEM image of jarosite crystals; b) TEM; kaolinite crystal and "spheres" of amorphous material. 
guano supplied phosphate ions. Ankerite occurs in areas where the cave walls consist of metamorphic carbonate rocks and is deposited from magnesium and iron-rich carbonate solutions. Gypsum is the most ubiquitous mineral, occurring on all types of substrates, both in limestone areas and in zones within micaschists and conglomerates, where it occurs inside the weathering deposits.

The large amount of secondary iron minerals discovered is due to the presence of pyrite concentrated in lenses or disseminated in all the other rocks forming the walls of the cave. The occurrences of these minerals within various lithologic settings give valuable information about their genetic environments. Jarosite forms in strongly acidic environments, while goethite requires weakly acidic or neutral environments. In many occurrences in the cave, one can observe a gradual transition from one mineral to the other (jarosite - goethite, \pm gypsum if calcium available) indicating gradual changes in the acidity of the solutions.

Two main factors are responsible for the cave minerals resulting from the non-karst rocks exposed in the cave. The first is the seepage water crossing micaschists and conglomerates and depositing mainly goethite crusts, flowstones and stalactites, with accessory jarosite, hematite and gypsum. The second is the humidity of the cave atmosphere, which creates extended weathering deposits on non-karst rocks no longer exposed to flooding by the cave streams. This resulted in a mineral association consisting of illite and kaolinite as main minerals, with variable amounts of jarosite, goethite and gypsum. The occurrence of these minerals, together with the extent of the weathering deposits developed on non-karst rocks make the Iza Cave an important site for the study of the karst water interaction with different bedrock lithologies.

\section{ACKNOWLEDGEMENTS}

The authors wish to thank the Administration of the Rodnei Mountains National Park for sampling and research permission. The help of cavers from the Montana Caving Club Baia Mare is greatly appreciated. Discussions with L. Ghergari, I. Viehmann, D. Istvan, and P. Häuselmann, and constructive comments from Dr. H.U. Kasper and an anonymous reviewer contributed greatly to the improvement of the manuscript. T.T. wishes to thank D. Sahy and M. Botez for their help during the various phases of this work, and A. Posmoşanu for permission to use the picture in Fig. 3. This paper is the $8^{\text {th }}$ contribution to the Iza Cave Project, initiated by Montana Caving Club Baia Mare.

\section{REFERENCES}

Balintoni I., 1997 - Geotectonics of metamorphic terrains in Romania. Editura Carpatica, ClujNapoca, 176 p. (Romanian).

Bercia I., Kräutner H. \& Mureşan M., 1976 - PreMesozoic Metamorphites of the East Carpathians. Anuarul Institutului de Geologie şi Geofizică al R.S. România, 50: 37-50.
Diaconu G. \& Morar, M., 1993 - Analyses minéralogiques dans la grotte "Peştera de la Movile" (Mangalia - Dobrogea de Sud). Karstologia, 22: $15-20$.

Ford D.C. \& Williams P.W., 2007 - Karst Hydrogeology and Geomorphology. John Wiley and Sons, Chichester, 562 p.

Forti P., Galli E. \& Rossi A., 2006 - Peculiar minerogenetic cave environments of Mexico: The Cuatro Ciénegas area. Acta Carsologica, 35 (1): 79-98.

Hill C.A. \& Forti P., 1997 - Cave Minerals of the World, second edition. National Speleological Society, Huntsville, 463 p.

Hill C.A., 1999 - Mineralogy of Kartchner Caverns, Arizona. Journal of Cave and Karst Studies, 61 (2): $73-78$.

Kräutner H.G., Kräutner F., Szasz L., Udubasa G. \& Istrate G., 1978 - Geological map of Romania 1:50,000, sheet 20d - Rodna Veche. Geological Institute of Romania, Bucharest.

Kräutner H.G., Kräutner F. \& Szasz, L., 1982 Geological map of Romania 1:50,000, sheet 20aPietrosul Rodnei. Geological Institute of Romania, Bucharest.

Mureşan B., 2010 - The survey of the Iza Upper Basin karst area. BSc thesis, Babeş-Bolyai University Cluj Napoca, 38 p. (Romanian).

Onac B.P., 1992 - Mineralogy of the Apuseni Mountains caves. Theoretical and Applied Karstology, 5: 193201.

Onac B.P., 2000 - Geology of Karst Terrains. Editura Didactică şi Pedagogică, Bucureşti, 399 p. (Romanian and English)

Onac, B.P. \& Forti, P., 2011 - State of the art and challenges in cave minerals studies. Studia UBB Geologia, 56 (1): 29-38.

Palmer A.N., 2007 - Cave geology. Cave Books, Dayton: $454 \mathrm{p}$.

Sahy D., Săsăran E. \& Tămaş T., 2008 - Microfacies analysis of Upper Eocene shallow-water carbonates from the Rodnei Mountains (N Romania). Studia UBB Geologia, 53 (2): 13-24.

Socolescu M., Diaconu F. \& Kissling M., 1961 Contributions to the knowledge of the mineralization from Valea Blaznei. Revista Minelor, 12: 253-258. (Romanian).

Strutinski C., Puşte A. \& Stan R., 2006 - The metamorphic basement of the Romanian Carpathians. Studia UBB Geologia, 51 (1-2): 1521.

Tămaş T. \& Ghergari L., 2003 - Hydronium jarosite from Iza Cave (Rodnei Mts., Romania). Acta Mineralogica-Petrographica, Abstract Series, Szeged, Hungary, 1: 102.

Tămaş T., 2009a - The Iza Karst system revisited (1977-2007). Exploration and survey. Proceedings of the 6th Symposium on Karst Protection, Belgrade, Serbia: 35-52.

Tămaş T., 2009b - Iza Cave. Proceedings of the Anniversary Symposium "From Pietrosul Mare to Rodnei Mountains National Park - Biosphere reserve - 75 years, Borşa, Romania: 191-194 (Romanian). 
Tămaş T., Sahy D., Mureşan B., Negrean O, Tămaş M. \& Minghirass T., 2009 - Iza Cave. The story of a re-survey. Speomond, 14: 24-30 (RomanianEnglish).

Tămaş T. \& Ungureanu R., 2010 - Mineralogy of speleothems from four caves in the Purcăreț-Boiu Mare Plateau and the Baia Mare Depression (NW Romania). Studia UBB Geologia, 55 (2): 43-49.

Udubaşa G., 1981 - Lithologic control of BlaznaGusset stratiform mineralisations from the Rodnei Mountains, Eastern Carpathians. Dări de seamă ale şedințelor Institutului Geologic al României, Zăcăminte, 65: 113-130 (Romanian).
Udubaşa G., Nedelcu L., Andăr A. \& Andăr P., 1983 Stratabound Lead-Zinc Pyrite Ore Deposits in Upper Precambrian Carbonate Rocks, Rodna Mountains, Romania. Mineralium Deposita, 18: 519-528.

Viehmann I., Silvestru E. \& Fabian C., 1979 - La Grotte d'Iza, Monts de Rodna, Roumanie. Travaux de l'Institut de Spéologie "Émile Racovitza", 18: 201-207.

Viehmann I., Demeter I., Lungu V. \& Sarkady. P., 1981 - Note préliminaire sur l'argile blanche de la grotte d'Iza (Monts de Rodna, Roumanie). Travaux de l'Institut de Spéologie "Émile Racovitza", 20: 213-215. 